\title{
A semiotic mapping of the study of literature
}

\section{Jorgen Dines Johansen}

In this century the relationship between the study of literature and semiotics has been close, even intimate from the very beginning, from Russian Formalism to the contemporary studies of the relation between literary studies and cognitive science. Their close relationship not withstanding, it must be remembered that they are separate, although overlapping, fields of inquiry each with relations to other disciplines and each with their specific issues and problems. Thus it makes sense to ask the question what semiotics has to offer literary scholarship.

In this article, however, I am only looking at one aspect of this relationship, namely the possibility of using a semiotic sign model to show the relationship of the different disciplines of literary scholarship in relation to one another. The model, which is based on Peirce's ideas of sign action, maps the exchange of signs between the two parties of a dialogue. I call it the semiotic pyramid:

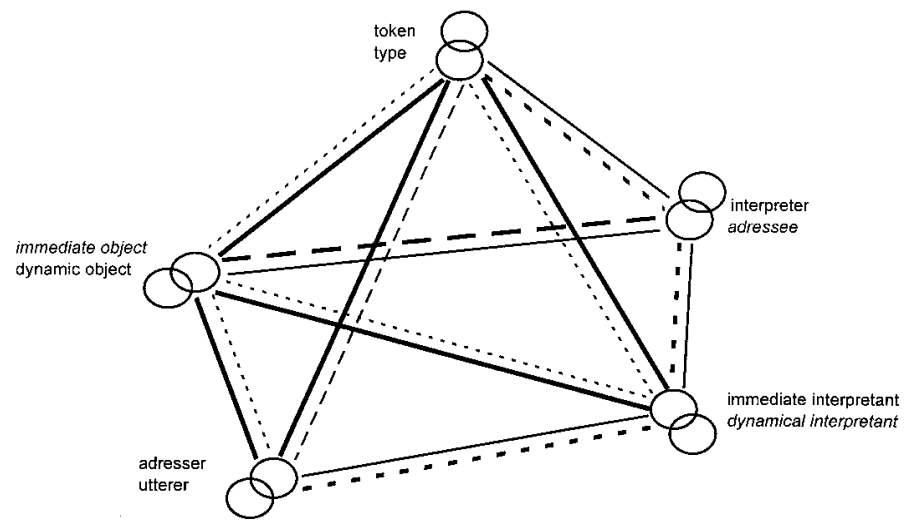


The diagram represents a dialogue between two persons, The solid line represents the semiosis seen from the point of view of the utterer. The dotted line the interpreter's point of view. In a verbal dialogue the sign will be instanced as a token emitted by the utterer, but to understand it the interpreter must identify it as a replica of a type and this involves an interpretation connecting it with object and interpretant. If the understanding between the parties is perfect (at least with regard to the purpose of the dialogue, and meaning implies reference to a purpose, cf. Peirce 5.175) ${ }^{1}$, utterer and interpreter will identify the token as an instance of the same type, the immediate object, or 'idea' referred to would (for the purpose) be sufficiently similar, among the possibilities offered by the immediate interpretants the interpreter would choose the one intended by the utterer, and each of them would understand and recognize their respective roles within the semiosis and accept them as persons. Moreover, dialogical communication can be corrected through explication by metalinguistic activity, reference to a common universe (e.g. through ostensive definition) by stating intentions and purposes, and by questioning.

This model is valid for literature as well as for everyday dialogue. Although it is an illusion that differentiae specificae exist which would enable us to distinguish literary texts from non-literary ones in every case, I find it worth trying here to point out some often used criteria. It must be added, however, that literary communication is many different things: The rapsodist reciting Homer vs. our solitary reading of a novel, not to speak of our watching a specific staging of a play.

According to universal pragmatics the relation holding between sign and object should be one of truth, i.e. the proposition expressed by the signs should correspond to a given state of affairs. This point of view seems sensible provided the existence of a dynamical object influencing the sign or at least existing independently of whether represented or not. One of the most often used criteria of literary discourse is, however, that it doesn't refer to a mind independent universe, i.e., the fictional universe is created by the sign itself.

In principle, we cannot know what kind of universe a text refers to by virtue of the text itself as Peirce points out:

In quoting from Peirce, I follow the convention of referring to the Collected Papers of Charles Sanders Peirce by letting the number left to the decimal point designate the volume number, while the number to the right designates paragraph number. 
In every proposition the circumstances of its enunciation show that it refers to some collection of individuals or of possibilities, which cannot be adequately described, but can only be indicated as something familiar to both speaker and auditor. At one time it may be the physical universe, at another it may be the imaginary "world" of some play or novel, at another a range of possibilities (2.536).

The reason is that the basic structure of the proposition (sentence) is the same irrespectively of whether referring to a historical or fictional universe:

\section{Alexander loves Roxana \\ Charles loves Camilla \\ Charles loves Emma \\ Donald loves Daisy}

In the first two cases we would presume that the persons referred to all belonged to the historical universe of discourse, although two of them are dead. The other Charles was, and is, never met apart from the pages of Flaubert's novel. The last couple inhabits the cartoon world, another separate, fictional universe, While obviously it makes sense to say that the first and second couple belong to the same universe, it makes no sense to say that Charles and Emma Bovary and Donald and Daisy Duck belong to the same universe. While there only one existing historical universe, an infinite number of fictional universes exists, because they may be produced at will.

Non-fiction vs. fiction, then, depends on which universe the texts indexical signs are referring to (or which predicates are ascribed to them, cf. below), and to know this we either need information from other sources, or we must rely on conventions. As regards fiction, we most often will lack additional relevant sources of information concerning certain important indexical signs within the text:

When the universe of discourse relates to a common experience, but this experience is of something imaginary, as when we discuss the world of Shakespeare's creation in the play of Hamlet, we find individual distinction existing so far as the work of imagination has carried it, while beyond that point there is vagueness and generality. (4.172).

Curiously enough, the so-called autonomy of a work of fiction, then, consists of a lack of information, or rather a lack of access to additional sources of information concerning the states of affairs represented in the fictional text. Most often the referential function of fictional indices simply stops short. 
Nevertheless, in order to understand the text as a sense-making totality, or to understand why it is not coherent, however, we have to presuppose what is not explicitly stated, but implied, or supposed to be implied, in the text. In furnishing the missing but needed information we, most often, act according to the "maxim of minimal departure" (coined by Marie Laure Ryan, see Ryan 1991), i.e., we project the interpretive habits, that we have developed through living and interacting within our life-world, onto the fictional universe. What can be mapped is, however, also governed by the specific features of the fictional universe in question: If seven-league boots are part of the props of a fairy-tale universe, we must willingly suspend our disbelief in the existence of such a means of transportation as far as that universe is concerned.

Nevertheless, the autonomy of fictional universes is relative indeed, because a fictional universe may be related to the experiential universe of our life-world in at least four ways.

1) Continuity: fictional indices function within a universe indicated by non-fictional indices. This feature is certainly pervasive in literature from antiquity onwards. Indeed from the times of the Homeric poems in which the actions were considered a part of both sacred and profane history to 19th century realism's setting of their narratives in contemporary society.

In Madame Bovary we have a wonderful description of the second town to which Charles and Emma Bovary move, it begins thusly:

Yonville-l'Abbaye $($ ), is a market-town some twenty miles from Ruon, between the Abbeville and Beauvais roads. It lies at the foot of a valley watered by the Rieule, a little river that runs into the Ardelle after turning three water-mills near its mouth; it contains a few trout and, on Sundays, the village boys entertain themselves by fishing. (Flaubert 1965: 49)

The other cities, or towns, and the river exist, but Yonville-L'Abbaye itself is not found in that part of France. Flaubert inscribes, with an almost deceiving precision his fictional town into real world geography; and Emma, and other characters, travel between this imaginary town and Rouen, which is the capital of Normandy. Here she commits her second adultery which is just as fictional as the first one committed in the fictional town and its vicinity. Such hybrid spaces are the rule rather than the exception in literature. And by embedding fictional spaces within non-fictional ones the relationship between world of fiction and life-world is strengthened justifying the 
"principle of minimal departure" as a sensible initial procedure. This continuity and contiguity between fiction an non-fiction very often imply another kind of relationship between the two worlds, namely:

2) Similarity: The fact that the fictional text imitates both the states of affairs and courses of events within the historical universe and our world of experience and the ways in which we are talking about and describing these matters. It is important to stress the latter point, since literary mimesis is primarily a representation of ways of using language in discoursing on our inner and outer worlds rather than a direct imitation of these worlds themselves.

Such claims to similarity are especially salient, when as, for instance in realism, the claim to world representation is strengthened to cover not only what is represented, but the mode of representation as well, for instance "realistic" dialogue in the theater, novels in dialect, the imitation of documents, etc. Let the following example suffice: On January 15, 1874 Ibsen writes to Edmund Gosse among other things responding to Gosse's criticism of Imperor and Gallilean. Gosse had wished that the play had been written in verse not in prose. Responding to this criticism Ibsen writes:

You are of the opinion that the drama ought to have been written in verse, [...]. Here I must differ from you. The play is [...] conceived in the most realistic style; the illusion I wished to produce was that of reality. I wished to produce in the reader that what he was reading was something that had really happened. If I had employed verse, I should have counteracted my own intention and prevented the accomplishment of the task I had set myself. [...] Speaking generally, the style must conform to the degree of ideality which pervades the representation. My new drama is no tragedy in the ancient acception; what I desired to depict were human beings, and therefore I would not let them talk the "language of the Gods." (Ibsen 1970: 269)

Of course, Ibsen is very careful to underscore that he wanted to create "the illusion of reality," but the point is that verse dialogue would, according to the aesthetics of realism, be absolutely detrimental to his project. However, throughout the history of literature, similarity as imitation has other definitions. At the one end we have ideas of decorum, both concerning what is allowed to become the object of imitation at all and which modes of imitation are proper to different realms of the experiental world. As regards the first point questions of propriety and, in the last analysis, questions of censorship are 
involved. Certain realms of common experience are excluded from literary interpretation, which and to what extent is historically and culturally variable (cf. that about 150 years ago Madame Bovary was tried — but acquitted — of immorality).

As regards the second point, the different genera elocutionis (see Lausberg 1960: §§1078-1083), for instance as represented in the famous rota Virgilii (the wheel of Virgil), in which the humble, middle, and sublimes styles are correlated with certain subjects and settings; indeed, even the names of characters were prescribed for the three styles.

However, it is not only within literature that what can be said, in which context, and in which ways are prescribed and enforced. Therefore literature's speaking and writing in accordance not only with le vraisemblable, but also according to les bienséances will, most often, in itself be an imitation of the ways in which society is discoursing on matters deemed delicate or outrageous. Furthermore, the fact that similarity is bound up with ways of seeing and representing means that literary representation and other ways of discoursing on the world are also similar, because, to a great extent, both are being governed by the same conventions.

3) Conventionality: Conventions understood as habits of action, speech, and interpretation are certainly pervasive, through upbringing and schooling they enter every realm of experience from intimate habits of hygiene to ways of perceiving and reasoning. As such they function as filters that are decisive for our understanding of the world. They are properly discussed, however, in connection with the relationship between signs and interpretants.

The link between literature and life-world may mean that (what is considered to be) laws, habits, and norms valid in a non-fictional world, thought to be continuous or homologous to the one represented in the literary work, are transferred to the fictional universe provided they are not, explicitly or implicitly, suspended by the fictional text. In a fictional work claiming to be true to "reality" the presuppositional network which grounds action, reactions, emotions, etc. ought to be the same within and outside the fictional universe. And in his letter to Gosse Ibsen does in fact claim that the characters in Emperor and Gallilean act in conformity with the actions of real people. This is really a claim that it is possible to understand the characters actions using the same presuppositual network that we would use in understanding other peoples actions. 
In addition, and contradistinction, to similarity and shared conventions between fictional and non-fictional universes, the fictional universe may distance itself, because of its marked otherness, it strangeness. In such cases the linking of life-world and literature may be figurative.

4) Figurative structuration: Elements and relations within the fictional universe are interpreted as figurative and intensified expressions of elements and relations within our life-world or psyche. This passage from Kafka's The Trial is an excellent exemplification of such a kind of relationship:

"Was ist das?" fragte er den Maler. "Worüber staunen Sie?" fragte dieser, seinerseits staunend. "Es sind die Gerichtskanzeleien. Wußten Sie nicht, daß hier Gerichtskanzeleien sind? Gerichtskanzeleien sind doch fast auf jedem Dachboden, warum sollten sie gerade hier fehlen?" (Kafka 1979: 141)

Unless you in fact believe it a feature of our life-world, at the time of Kafka, that every other attic in big cities housed court rooms you will either have to deny any connection between his fictional world and the contemporary life-world, or you must interpret these courts as figurative expressions of states of affairs, or of mind, that are encountered in the world of that day. In fact, at least two standard interpretations linking Kafka's world to the world of his own times, and to our, exist. The first means considering the courts as figurative expressions of actual states of affairs: The setting is taken to signify that in police states surveillance and secret and unjustified trials and convictions are going on all the time. The rhetorical figure used here is the hyperbole. The second interpretation sees the courts in the attics as an expression of the cruel super-ego of the main character (or the narrator), and thus, the setting becomes metaphorical. Such readings are allegorical in the sense of medieval interpretive practice ${ }^{2}$.

2 Concerning the relationship between literal and allegorical interpretation let the following observation of Dante's suffice:

Writings may be understood and ought to be expounded chiefly in four senses. The first is called literal (and this is that sense which does not go beyond that enunciated by the fictitious word, as in the fables (favole) of poets. The next is called allegorical, and this is that which hides beneath the mantle (manto) of such fables, and is a truth hidden beneath a beautiful falsehood: such as when Ovid says that Orpheus tamed wild beasts with his lyre and made trees and stones move towards him, which 
The point is that it is not the literal fictional universe that is compared to and interpreted in the light of our life-world, it is the interpretation of it in abstract statements about forces and conflicts in the outer or inner world. It is even often the case that a literary text will be related to the life-world of its origin in all four ways, and thus it is complicated, indeed, to describe the exact nature of the relationship between the two worlds.

However, there may be a fruitful way of understanding this relationship, a way we already find in Aristotle. On his view, the delight we take in literature is caused by two innate instincts: that for representation and that for tune and rhythm. About the former he says in the Poetics:

From childhood men have an instinct for representation, and in this respect man differs from the other animals that he is far more imitative and learns his first lessons by representing things. And then there is the enjoyment people always get from representations. What happens in actual experience proves this, for we enjoy looking at accurate likenesses of things which are themselves painful to see, obscene beasts, for instance, and corpses. The reason is this. Learning things gives great pleasure [..] to [..] men [..]. The reason why we enjoy seeing likenesses is that, as we look, we learn and infer what each is, for instance, "that is so and so." (Aristotle 1927: 13-15, 1448b)

Now, the acquisition of knowledge through contemplation of likenesses means making inferences about the nature of a given phenomenon by using a model of it. Understanding a model as an iconic representation, a likeness, is common in semiotics, cognitive science, the philosophy of science, and within literary scholarship.

There is a benign polysemy in the word 'model,' since it may signify a number of things among which the following are interesting from our point of view: (1) The construction and representation of the phenomenon as an object of knowledge by means of signs, as, for instance the mapping of relations between objects in the external world as relations between elements of pictures, maps, verbal descriptions, and mathematical relations - of course, outside all representation the external objects are not comprehended at all. Further a (2)

shows how the wise man makes cruel hearts grow tame and humble with the instrument of his voice, and how he makes those who have no feeling (vita) for science and art moving according to his will; and those who have no rational life at all are little better than stones. (Dante in Minnis, Scott, and Wallace 1988: 396). 
'model' may be a prototype, for instance, a new model of a car is a prototype. Another signification of 'model' related to 'prototype,' but nevertheless different is (3) 'ideal,' or 'exemplar,' somebody may be a model of virtue or beauty.

According to Juri M. Lotman, literature as a model is an iconic representation, or an analogue, of the object it represents. The individual model belongs to a modelling system, and in literature's case to a so-called secondary modelling system, i.e., a system built upon language as the primary modelling system. A modelling system consists of an inventory of elements and their combination rules together with an analogical relation to the object. The literary work of art is, at one and the same time, a translation of the object into the elements and relations of the system and its analogue. In other words, a literary text is always, at the same time, conventional and the likeness of a given object, and being an icon scrutinizing the sign will teach us about the object (the parallel to Aristotle is obvious) ${ }^{3}$.

However, how and of what are literary texts models? According to Max Black, standard cases of models are miniature, three dimensional models, scale models, of "some existing or imagined material object" (Black 1962: 219), such objects he calls originals of the models Representational painting must in certain respects be considered, and fruitfully treated, as two dimensional, and representational sculpture as three dimensional, scale models. Literature cannot, however, generally be treated as a scale model, because a scale model's conventions of interpretation "rest on partial identity of properties

Of Lotman's examples of such models maps, on the one hand, and play and games, on the other, should be mentioned (he also mentions military drill and exercise). Maps are related to the territory in three ways: indexically because they are influenced by the territory through measurements, projections, etc., iconically because in certain specified ways maps are like the territories they depict, and symbolically because a lot of conventions are used in mapmaking. Plays and games both imitate patterns of behavior and interaction and are clearly conventionalized and rule-governed activities. Maps, playes, and games are alike in helping us to act in our life-world. In fact, a map will often be the only way in which we will be able to comprehend the structure of a city, and thus to find our way. Playing and games are helpful models of interaction, because they allow to interrupt the action, and to repeat and correct it. Furthermore, situations in actual life that are unpredictable, seemingly amorphous because bewilderingly filled with details, and irrepeatable, are simplified and manageable according to a finite set of rules. 
coupled with invariance of proportionality" (ibid. 220), and obviously literature consists of strings of symbolic signs that do not share the properties of what they represent or depict.

Black mentions three other kinds of models, analogues, mathematical, and theoretical models. The two latter have little relevance to literary mimesis (although there is an affinity between metaphors and theoretical models). It seems fruitful, however, to consider a very dimension of literary texts as an analogue of an existing and/or imagined universes. Like Peirce and Lotman, Black also sees such a model as iconic, but in a more abstract sense than the scale model, instead of partial identities of properties an analogue is isomorphic with its original, it displays the same "structure or patterns of relationships" (ibid. 223), i.e., an identity of structure not of qualities. Remembering Ryan's principle of minimal departure, one could say that the reason why representations of fictional universes may, and do indeed, serve as models of human existence is that they are construed and understood according to the conventions used in interpreting lifeworlds.

However, it must be remembered as well (1) that models are purposeful simplifications of the object represented, and that (2) creating new worlds means using and transforming the elements and patterns of other worlds. Philosophers differ on the question whether there is one basic world, or basic world-version, from which all others are built. A radical relativist like Nelson Goodman denies both the defensability and usefulness of this idea. He points out, however, that:

For the man-in-the-street, most versions from science, art, and perception depart in some ways from the familiar serviceable world he has jerry-built from fragments of scientific and artistic tradition and from his own struggle for survival. This world, indeed, is the one most often taken as real; for reality in a world, like realism in a picture, is largely a matter of habit. (Goodman 1978: 20)

Even if one disagrees with his philosophical position, Goodman is certainly right in claiming that our interpretations of the life-word is sketchy, fragmented, and incoherent ${ }^{4}$. Departing from the habitual

4 At first glance, what has been said, leave us with conflicting points of view: On the one hand it seems that the idea of literature as a model of the life-world presupposes that there is (1) a basic world to be represented, and (2) that there are true and false ways of representing it, i.e. models that are true or false. On the other hand, it seems that (1a) the world itself only exists in different representations, and that consequently (2a) there are no standards 
element in our world experience, Goodman points out that artists' vision differ from, or may differ from, our perceptive and interpretive habits:

Many of the differences among portrayals by Daumier, Ingres, Michaelangelo, and Rouault are differences in aspects accentuated. What count as emphasis, of course, is departure from the relative prominence accorded the several features in the current world of our everyday seeing. With changing interests and new insights, the visual weighting of features of bulk or line or stance or light alters, and yesterday's level world seems strangely perverted - yesterday's realistic calender landscape becomes a repulsive caricature. (Ibid. 11)

Goodman sees world making as an activity where, departing from some already existing world version, a new world is created by the following five procedures: (1) Composition and decomposition, i.e., making distinctions and identifying and naming elements, organizing them according to that particular world. (2) Weighting or emphasis (see the quotation above). (3) Ordering including systems of divisions such as, for instance, the different calendars. (4) Deletion and supplementation, according to Goodman "our capacity for overlooking is virtually unlimited, and what we do take in usually consists of significant fragments and clues that need massive supplementation. The relevance of these two structuring devices to literature is obvious. Finally (5) Deformation, for instance, of a given representational habit, e.g. a caricaturist in his drawing deforming the face of his victim.

As regards literature there is a specific difficulty, because the world relevant to it is the historical world of human interaction which, of course, is the most complicated province of the universe. Its complexity is due to its double dependence on human minds. It is not

according to which the models can be judged. However, although different world descriptions cannot be reduced to a single one, it may plausibly be argued, that, at a given level world versions may be tested and their rightness judged according to a series of tests. Thus, good reasons for preferring one version over another may be given, although final proof is unavailable.

Further, it seems to me, that there is one very good reason for ascribing a privileged position to the experiental world and taking it as point of departure in interpreting other worlds, namely that we are bodily present in it, we perceive, act, and suffer and die within it. Thus, poets, artists, scientist, and indeed, although it sometimes seems doubtful, even philosophers are also men-in-the-street. 
only dependent in the sense of being given to and only accessible through the mind, but also because it is to a great extent made up of human ideas and beliefs, wishes, passions, and norms and actions. In other words, it is inherently endowed with meaning and interpreted in multiple and conflicting ways, before it ever functions as an original to become represented in a model. Since no commonly accepted version of the historical and experiental universe exists, there will also be multiple ways of making models of it. A further consequence of the mind-perfused nature of the historical-experiental world is that a model of it may legitimately reflect norms and ideals in the very way it is structured ${ }^{5}$. This is why, to Aristotle, such things lie at the very heart of poetic representation:

Since living persons are the objects of representation, these must necessarily be either good men or inferior [..] that is to say either better than ourselves or worse or much what we are. [..] For instance Homer's people are "better", Cleophon's are "like", while [..] in Nicochares, the author of the Poltrooniad, they are "worse". (Aristotle 1927: 11, 1448a)

The precondition for this division is that we know what we are like, but do we? The enlightening answer to this question may be that we do and we don't. We hold reasonably well founded beliefs and opinions concerning the general motivations of people and their patterns of interaction - in a given period within a given culture. We also know the, most often conflicting, norms and ideals according to which people are supposed to act, and the general ways in which compromises are made between such norms and strivings for survival and personal interests and advantages. Individual, singular action, however, cannot be predicted with certainty, although it may be explained afterwards — but again only beyond reasonable doubt. Furthermore, both heroic and ridiculous actions do happen in real life; and thus, the range of ethical greatness, medium, and baseness is well known within our life-world.

It would certainly be preposterous to deny the use of originals, because imagination without memory is unthinkable; and obviously characters in an individual literary text may well have individual, historical persons as originals. There are, however, two main reasons why the use of originals in literature is very complicated: First,

Max Black suggests to disregard the senses "in which a model is a type of design — or, on the other hand, something worthy of imitation" (Black 1962: 219), but precisely this is impossible, when dealing with literature. 
fictional characters are very often amalgams of several originals, in addition to much which is unidentifiable ${ }^{6}$. Second, even if it is possible to point to individual originals for a fictional character, the fictional universe in toto, i.e., the product of the fictional space with its different backdrops, sets, and props, and characters moving within it during a fictional time, is structured in a way that will not precisely match any non-fictional universe. Further, and more importantly, the literary text has also features in common with the scale model of parts of species and kinds, such as the model of the human female skeleton, because literature is concerned with what is considered typical. Indeed, the idea that literature is a concrete and particular embodiment of what is (supposed to be) universal has been claimed of and for it since Aristotle (see Poetics, chapter 9, 1451a-b).

Literature, as a model, functions much in the same way as the use we make of the concept, when we say that somebody is a model of something, courage, beauty, evil, etc. In saying so we abstract from other features of such a person. The paragon of courage is, at the same time, a lot of other things, but we use him or her to exemplify this quality. Literature, of course, may, to use E. M. Forster's term (see Forster 1927), represent 'round characters,' i.e. characters endowed with multiple features, but still characters and society in a literary text (and even in George Eliot or Proust) are composed of a limited set of features. There is another aspect to this, which is brought to the fore when genre conventions are prominent, namely the fact that features are selected according to certain rules. Aristotle's ethical distinction between tragedy and comedy is an example hereof: "The latter sets out to represent people as worse than they are to-day, the former as better" (ibid. 11, 1448a). This means that literature offers several conflicting models of our life-world, each structured according to different sets of internal conventions (cf. Lotman). One of the enjoyments, literature offers, is precisely a certain purity, or one-sidedness of representation. However, in saying that the literary text represents an object, the imaginary universe, it must not be forgotten that the source of the immediate object of a fictional text is not a dynamical object, but an author who on the basis of his experiences, i.e., by being himself influenced by dynamical objects, but also by other texts representing

6 We read, for instance, in Amos (p. 211) that Oriane Duchesse de Guermantes in Proust's Remembrance of Things Past is an amalgam of Comtesse Adhéaume de Chevigné (1860-1936); Comtesse Henri Grefulhe (18601952), and Mme Émile Straus (1846-1926). 
fictional universes, offers a certain vision that only exists by virtue of his text. Literature, most often, does not immediately represents originals, it offers interpretations of them in texts representing immediate objects only mediately connected with dynamical, mindindependent, ones, the mediating agent being the author.

However, before going into questions concerning the relationship between text and author, we should ask whether certain patterns, although they are present in other types of discourse, are prominent in literature.

Not surprisingly what comes to mind are the phenomena described in the treatises of rhetoric and poetics, the figures and tropes, rules of diction, meter, stanza forms, principles of composition and narration. Here I cannot go further into these aspects of the literary text, i.e., its self-reflexive properties, the fact that parts of the text on different levels from phonemes to stanzas or chapters mirror each other. And, on my view, literature is characterized by the interaction between its self-representative and other-representative features (for a semiotic approach to these aspects see my article "Iconicity in Literature," 1996).

In linguistic texts, the source of the sign is not the dynamical object, but the utterer. The text, represents his perception og the world as it is articulated according to codes and cognitive models, of which he shares by far the biggest part with the fellow members of his culture and society.

Problems concerning the relations of utterer to text, to the world it represents, and to the hearer are studied by, among others, the speech act theory of analytical philosophy and linguistic pragmatics. Within literary studies these problems have also been intensively studied by American (e.g. Wayne Booth), German (e.g. E. Lämmert and F. Stanzel), and French (e.g. G. Genette) scholars. I do not intend to go either into the questions of mood and voice, or into the different types of narrators.Rather I will briefly inquire into the relationship between utterer and addresser, or as this distinction is named within literary studies, author and narrator.

Classical rhetoric was seen as the art of persuasion, and according to Aristotle, the means of persuasion are three:

Now the proofs furnished by the speech are of three kinds. The first depends upon the moral character of the speaker, the second upon putting the hearer into a certain frame of mind, the third upon the speech itself, in 
so far as it proves or seems to prove. (Aristotle 1926: 17, Book I, ii, 3, 1355b-1356a)

Since rhetoric deals with the probable, not with certain knowledge, the trustworthiness of the speaker becomes important. Accordingly, the first task of the orator is to ensure the attention of the audience. Secondly, he has to persuade them of his credibility and reliability. The second kind of proof is, according to Aristotle, the rousing of a certain emotional state in the hearers, "for the judgment we deliver are not the same when we are influenced by joy and sorrow, love or hate" (ibid.). Thus, benevolence becomes an essential ingredient in the construction of the image of the addresser in the sign, because the audience ought to be persuaded that what is advised and prescribed is in its own interest. The orator's task, then, is triple, it consists in gaining the attention and sympathy of the audience, of eliciting a certain emotional attitude towards the object of the speech, and of persuading the audience that the recommended decision will further their happiness or pleasure (cf. rhetoric's general precept that the office of the speech is to teach, to please, and to move).

In spite of Quintillian's claim that in order to be a good orator you must be morally good, orators do attempt to control the listeners by pretending, not for the good of the audience, but in order to securing personal advantages. In such cases the split between utterer and addresser, which makes pretense possible, has been exploited.

The effort to bridge the split between utterer and addresser is well explained by our obvious interest in not being cheated by the pretense of others. The signs emitted by the utterer inform us not only about a state of affairs, they also indicates his relation to the stated, his socalled propositional attitude, i.e., whether he believes it, recommend it, promises to do it, warn us not to do it, etc. These indications create the addresser of the sign, i.e., the utterer as he appears in and by virtue of the sign. We are to a great extent responsible for the personae we create, because of consequences and obligations bound with them. We may even be taken to court to account for what we have said or written.

In additions to the important question of accountability, there is another reason for the obsession with the origins of texts, with the question of their source, namely their expressivity, the fact that they are symptoms. Focus is changed from the object they represent to the state of mind of their utterer which they are supposed to reveal. It seems that we can hardly bear the uncertainty that the split between 
utterer and addresser creates. We try to overcome it, as if it were a wound which should be healed.

Sometimes it seems as if the effort to hold people responsible for the signs they utter and the search for their other, non-obvious meanings are at odds, but this is explained by the fact that in holding people accountable we refer to a generally recognized standard meanings of words and phrases. In inquiring into the expressivity and symptomatic value of sign, on the other hand, we search the specific context and specific context of utterance for indices of individual attitudes. In the last analysis, there is no contradiction involved in, at one and the same time, to hold somebody responsible for not keeping a promise and interpreting the uttering of it and its phrasing as a symptom of vanity.

In literature we have, as John Searle has pointed out (see Searle 1979), quite another kind of benevolent pretense: The author pretends to refer to states of affairs as if they had really happened. In case of literature, an agreement of sorts exists between writer and readership to the effect that nobody is neither fooled nor harmed. In literature there is, however, another side, another kind of doubleness, to the relationship between author and narrator (or poet and the lyrical I of the text), because the abolishment, or at least attenuation, of sincerity and accountability makes possible an inquiry into dimensions of subjectivity that, in most cases, are inaccessible in non-fictional discourse. The apparent paradox is that the license to create a number of personae, that are definitely not identical with the utterer, make it possible to know more about his mind - and ours as well.

On reflection, this is not surprising, because the liberty to create a fictional world told by a number of fictional narrators, means the possibility of denying any direct relation to and responsibility for what is narrated. That which is told is presented as a kind of reported speech for which the utterer is a medium rather than a responsible originator.

Although nobody is really fooled by this pretense, it suffices to bring into play figments of imagination that otherwise would hardly be communicated to an audience. This is why literature, among other things, constitutes an attempt to write up against and possibly pass limits of self-exploration that are not often crossed. This is why the Danish storyteller, Isak Dinesen, in "The Cardinal's First Tale" let the cardinal himself answer the lady in black's question about his identity by telling her a story. After he has finished his tale, he concludes that 
the story alone can enlighten us about our identity: "For within our whole universe the story only has authority to answer that cry of heart of its characters, the one cry of the heart of each of them: "Who am I?'" (Dinesen 1957: 26, Last Tales, London, Penguin)

This, of course is not only valid for modern literature. A tragedy such as Oedipus Rex stages questions of identity, and one of the offices of literature in general is to make possible conversation and reflection on identity, even if its involves that which is both improper and dangerous. This is why the story's power to enlighten us about ourselves is due to the hypothetical nature both of its plot and world and of its narrators. In spite of the plain truth of Genette's claim that "to tell a story and therefore to "report" facts (real or fictive), its one mood, [..] strictly speaking can only be the indicative" (Genette1980: 161), fictional narrative is not concerned with what has been, but with that which might have been (cf. also Aristotle's Poetics, 9, 1451b). Obviously, it is a real utterer who reports, not what has happened, but what has been imagined (a hypothetical state of affairs imagined by an individual or collective mind), but in doing so, as a narrator, he becomes infected, as it were, with the unreality of the story.

This imagining mind, however, is split between its origin, the historical-experiental universe, where it resides in the body, or bodies, of the utterer(s), and the fictional universe in which it functions as the creative and structuring principle. Thus, the fictional voices are also necessarily parts of the mind of the utterer that are projected into the text.

Literature makes it possible to speak yourself as if you were another, or rather others. At first glance, it seems a trivial fact that the author is neither the narrator nor the protagonist, it is, however, the precondition for a less trivial fact, namely an amalgamation of self and other. And it is this amalgamation of self-as-other and other-as-self that makes possible the emergence of what would otherwise never appear.

It might be objected that, in the final analysis, such texts are masquerades, and that behind the masks there is nothing but one self, the utterer. Such a position confounds bodily identity with conditions for sign production. Obviously, there is no denying that the main physical source of a text often is an individual brain in an individual body. The point is another one, namely that the creation of an alter, of something which, in spite of its being a creature of the same brain, is 
conceived as a non-I, will call forth significations impossible without this interplay.

Testimonies to the complex relationship between author and text are the following two passages that are both exemplary, but pointing in different directions. Concerning his play, The Father, Strindberg writes to Axel Lundegård on Nov. 12, 1888, letter 1460: "It seems as if I were a sleepwalker, as if fiction and life merged. I don't know whether The Father is a play or whether my whole life is one." (Strindberg 1958: VI, 298 my translation). According to T. S. Eliot: "a good love poem, though it may be addressed to one person, is always meant to be overheard by other people. Surely the proper language of love - that is, of communication to the beloved and to no one else is prose" (Eliot 1957: 90). On the one hand, writing literature involves the writer to an extent that hardly makes it possible to distinguished non-fictional from fictional, but, on the other, in writing the author is always performing in front of an audience. The point is that both are true of this relationship, and they are true at the same time.

One aspect of this interplay is the possibility of what the psychoanalysts call denial. This mechanism allows the patient the double operation of stating and denying: "It was not my mother" says the patient, at one and the same time, putting into words what occupies and troubles him and denying its truth and reality. As regards literature, it is its institutionalized framing that, even before the individual writer starts writing, guarantees, indeed implies, that what is written, belongs to the realm of the non-I, narrates about the nonme, and obliges nobody.

It is this negative relationship between literature, subject, and lifeworld that makes it possible for fiction to probe into the core of the nature of subjectivity and its preconditions, i.e. how it is formed by social constraints and discursive practices. It is only by pretending to not being sincere, that that which is our main concern can be narrated and become subject for scrutiny that is less restricted by considerations of safety, personal advantage, propriety, common sense, and social and political power.

Concerning non-literary texts, a, sometimes unremitting, effort to tie the signs to the person exists for the very good reason that there is an important contractual aspect to very many utterances. However, even as regards literary texts, that in principle are separated from their authors, this effort is prominent. In spite of all protestations from writers to the opposite, in spite of all the fine theoretical reasons for 
not mixing up the production of fiction with the personal life of the writer. It is as if there is a deep-rooted desire in readers to tie the narrators, and the text in general, to its author and to making him accountable for it. In the last resort, censorship has never respected the borderline between fictional and non-fictional texts. Poets and writers of fiction have been, and still are, persecuted as well as writers of political pamphlets.

To a great extent the relationship between utterer/narrator and reader/interpreter is symmetrical. Concerning the utterer it was claimed that creating one or more voices, with a fictional identity, who are narrating about what has never happened, means access to and wording of what would otherwise remain unsaid. These reports about nonexisting state of affairs, or about states of mind created with art, are directed to an audience or readership whose characteristics the texts attempt to specify before they reach the actual listeners or readers.

According to classical rhetoric, the orator must be able to make the audience accept the way in which it itself is represented in his speech. Thus the text models its immediate interpreter who is the interpreter as he appears in, or is indicated, by the sign itself as a function of the purpose and the structure of the text, let us call him, or rather this role, view point, and set of values and norms pointed out by the text, the addressee. The split between addresser and interpreter, then, is between a textual construct and the actual interpreter. Just like the addresser, the addressee or implicit reader is a kind of persona, a mask, that the actual reader is offered, but, obviously, the actual interpreter may refuse to wear it.

Genres such as joking, for instance are extremely vulnerable to the resistance and refusal of the interpreter. According to Freud, the utterer of a joke needs the laughter, and thereby approval, of the interpreter in order to enjoy his own joke and to release his own laughter. This is especially important, if the joke is tendentious, obscene or aggressive, directed against a third party (see Freud 1905). In such cases the interlocutor may easily destroy the joke simply by refusing to take upon him the role of the presupposed addressee. In doing so he or she will, implicitly or explicitly, question the standards according to which the utterance is supposed to be witty. And since values and morals change rather dramatically in and throughout time and space, such redefinitions are going on all the time. It should also be remembered that in dictatorship countries the very possession of certain texts doomed subversive and immoral is often sufficient reason 
to incur punishment, because the owners automatically, and maybe unjustly, are identified as the addressees of these texts.

There are good reasons for the resistance of the actual interpreter concerning texts pertaining to our life-world. Texts are the means used to negotiate not only what is supposed to be an adequate description of the world, what is good and what is bad, but also the place and position of the interlocutors within it, their duties and privileges. Consequently, texts and dialogue are used to establish a consensus, or to realize that differences are irreconcilable.

But why is there just as much resistance to texts representing a world categorially different from the world within which writers and readers live and interact? Obviously, part of the answer has to do with the fact that literary texts underscore questions and problems of value and of the validity of accepted interpretations of the human condition. Literary texts function as means to test conditions and consequences of a given morality within an imaginary world.

Although there is little doubt that literature does question common norms and ideas, I do not find this is sufficient reason for the often violent reactions to it. It has to be added, I presume, that the mental processes active in reading fiction predispose the reader to react emotionally. In order to make sense of a fictional universe of discourse the reader has to supplement what is not mentioned, but presupposed. There is, however, an indefinite, but probably rather limited, number of equally valid ways of realizing what is indicated but not specified in the text. Especially in the translation of the symbolic signs of the text into iconic ones, as for instance when a character or scene is imagined, there will be widely different solutions determined by the experiences of the individual reader, but still translations that lie within the possibilities delimited by the significations of the linguistic text. This means that the text becomes invested with fragments of the reader's former experiences, and thus also with the love and hate, and with the triumphs and humiliations he or she have gone through.

In reading, the reader makes room within his mind for a highpowered and highly structured mental model sketched by somebody else, but left to himself to finish as best he may. This is why mechanisms of introjection, projection, and identification are necessary means in the reader's construction of the imaginary universe. Because of this internal dialogue between self and other which is going on unconsciously as well as consciously, the literary 
text is able to stir up emotions and make people react in a much more passionate way than should be expected from a purely practical point of view. At the same time, however, the literary text does not offer any direct possibility of action, because the only access to its universe is through imagination. This means that works of literature become individualized models for the contemplation of the human condition, at a given time and place.

An important homology exists between the relation between object, sign, and interpretant, on the one hand, and utterer, sign, interpreter, on the other. First of all, in viewing semiosis as a directional process, both object and utterer are sources of the sign, and both interpretant and interpreter are influenced by the sign. Second, it seems sensible to hold that the latter semiotic process (utterer, sign, interpreter) presupposes and is derived from the former (object, sign, interpretant), because communication is about something, and, logically, information concerning the object precedes dialogizing about it (but obviously the dialogue itself may become the object of discourse). Third, and this is here my main concern, the dialectic of self- and other-representation that is so important in the interplay between universe and textual patterning in literature, is present and equally important in the relationship between utterer and interpreter via and by virtue of the sign. Just as the object is only made definite and understandable by virtue of the interpretant(s), and the interpretant(s) challenged and influenced by the object, so do utterer and interpreter, and their textual personae, addresser and addressee, reciprocally articulate and define each other. And in literature, precisely because of the attenuation of responsibility, obligations, and practical consequences, the interpenetration of self and other may be more thorough than is possible in daily business. Thus, reading literature not only means an effort to realize an imaginary universe by means of both collective and individual resources (semiotic competence, knowledge, memory, and fears and desires), it also means allowing oneself, not only to understand the points, angle, and purpose of the other party of the dialogue, but to take over another view and perspective, almost making it one's own. And making room for another mind, including unconscious significations and pulsations, means enlarging one's own.

Literature or fiction in general, is so important, because it not only offers a model, distorted, ideal, grotesque, or seemingly to the point, of the human condition, it offers the image of a passionate struggle with it. 


\section{References}

Amos, William (1985). The Originals. Who's Really Who in Fiction. London: Sphere Books.

Aristotle (1926). Art of Rhetoric (trans. J. H. Reese). London: Heineman (Loeb).

Aristotle (1927). The Poetics (trans. W. Hamilton V). London: Heineman (Loeb).

Black, Max (1962). Models and Metaphors. Ithaca: Cornell University Press.

Booth, Wayne (1961). The Rhetoric of Fiction. Chicago: Chicago University Press

Eliot, T. S. (1957). On Poetry and Poets. London: Faber and Faber.

Flaubert, Gustave (1961/1857). Madame Bovary. Mours de province, E. Maynial (ed.). Paris: Garnier.

Forster, E. M. (1927). Aspects of the Novel. London: Edvard Arnold.

Freud, Sigmund (1905c/1960). Jokes and Their Relation to the Unconscious.

The Standard Edition of the Complete Psychological Work of Sigmund Freud, vol. VIII. London: The Hogarth Press.

Genette, Gerard (1972). Figures III. Paris: Èditions du Seuil.

Genette, Gerard (1983). Narrative Discourse. Ithaca NY: Cornell University Press.

Goodman, Nelson (1978). Ways of Worldmaking. Indianapolis: Hackett Publishing Company.

Ibsen (1970): The Correspondance of Henrik Ibsen, Mary Morison (ed.). New York: Haskell House Publishers.

Johansen, Jørgen Dines (1996). Iconicity in Literature. In Semiotica 110(1/2), $37-55$.

Kafka, Franz (1979). Der Prozess. Frankfurt a. M. Fischer Bücherei.

Lausberg, Heinrich (1960). Handbuch der literarischen Rethorik I-II. München: Max Hueber Verlag.

Lämmert, Eberhart (1955). Bauformen des Erzählens. Stuttgart: Metzler.

Minnis, A. J., Scott, A.B., and Wallace, D. (1988). Medieval Literary Theory and Critcism c. $1100-c$. 1375. The Commentary Tradition. Oxford: Claredon Press.

Peirce, C. S. (1931-1958). Collected Papers, Ch. Hartshorne, P. Weiss and A. Burks (eds.). Cambridge (Mass.): Harvard University Press.

Ryan, Marie-Laure (1991). Possible Worlds, Artificial Intelligence, and Narrative Theory. Bloomington: Indiana University Press.

Searle, John (1979). Expression and Meaning. Cambridge: Cambridge University Press.

Stanzel, F. K. (1955). Die typischen Erzählsituationen im Roman. Wien: Wilh. Braumüller.

Strindberg (1958). August Strindbergs Brev, T. Eklund (ed.) (= Strindbergselskapets Skrifter vol. 6). Stockholm: Bonniers. 


\section{Семиотическая картография науки о литературе}

В статье рассматриваются возможности приложения семиотической модели диалогических отношений к взаимодействию между различными аспектами филологической проблематики. В первую очередь автор рассматривает вопрос о референции текста к конструируемой им реальности. Сложность проблематики состоит в том, что формальная структура любого высказывания не зависит от того, к какой именно "реальности" она отсылает - например, к исторической или литературной. Для понимания текста необходимо задействовать и не эксплицированные в нем механизмы, включающие индивидуальный интерпретационный опыт, как литературный так и жизненный, каждого реципиента. Так, чтобы определить семимильные сапоги как принадлежность сказочного мира, необходимо задействовать и литературный опыт чтения текстов подобного рода и опыт отсутствия аналогов в нашей реальности. Таким образом можно говорить только об относительной автономии литературного мира и мира реального опыта.

Далее автор предлагает четыре принципа соотнесенности или соответствия между реальным и художественным миром. Принцип целостности, согласно которому вымышленные элементы текста равноправно сосуществуют с верифицируемой реальностью (например, географической). Принцип подобия, состояший в том, что литературный текст имитирует как события, располагающиеся непосредственно в истории и в мире нашего опьта, так и то, каким образом мы говорим о них или их описываем. Принцип конвенциональности, предполагающий обшность усвоенных реципиентом и представленных в литературном тексте конвенций. Принцип образной упорядоченности, при котором система элементов реальности регулярным образом соответствует системе риторических элементов произведения. Все способы и принципы уподобления текста реальности действуют как способы построения "моделей" в их отношениях к “оригиналам", при этом учитывается способность творчества предлагать и реализовать одновременно несколько конфликтуюших моделей. Отношение к реальности строится по законам классической риторики в аристотелевском варианте и состоит в убеждении и доверии воспринимающих. В статье подчеркиваются также обучающие и когнитивные свойства "модели". Отношения между автором ("моделируюшим")/повествователем и читателем/ интерпретатором строятся по законам симметрии. Для успешного установления понимания необходимо, чтобы читатель или аудитория приняли соответствуюшую им “модель". Важнейшим связую- 
шим звеном между ними является то, что и автор текста и интерпретатор пользуются одним языком для описания как бывшего, так и не бывшего.

Таким образом, чтение литературы предполагает специфическое усилие по пониманию воображаемого мира средствами как коллективного, так и индивидуального опыта, а также не только понимание точки зрения, задачи другого участника диалога, но и в определенной степени присвоение его позищий.

\section{Kirjandusteaduse semiootiline kartograafia}

Artikkel käsitleb semiootilise dialoogi-mudeli rakendusvõimalusi filoloogilise problemaatika erinevate aspektide omavaheliste seoste uurimisel. Eelkõige vaatleb autor teksti suhet tema poolt konstrueeritud reaalsusesse. Antud problemaatika keerulisus seisneb asjaolus, et lausungi formaalne struktuur ei sõltu sellest, millisele 'reaalsusele' ta viitab (nt. ajaloolisele või kirjanduslikule). Teksti mõistmisel on vaja kaasata ka selliseid tema poolt eksplitseerimata mehhanisme, nagu retsipiendi enese individuaalne kirjanduslik ja eluline kogemus. Näiteks, selleks et pidada "seitsmepenikoorma saapaid" muinasjutumaailma kuuluvateks, on vajalik teatud kirjandustekstide lugemise kogemus ja kogemus, mis lubab järeldada vastavate analoogide puudumist reaalses maailmas. Seega on kirjanduse maailma ja reaalse kogemuse maailma autonoomia vaid suhteline.

Edasi kirjeldab autor nelja printsiipi, mis iseloomustavad reaalse ja kirjandusmaailma seoseid: 1. Terviklikkuse printsiip, mille kohaselt teksti fiktiivsed elemendid koeksisteerivad kui võrdväärsed verifitseeritud (nt. geograafilise) reaalsusega. 2. Sarnasuse printsiip, mis seisneb selles, et kirjanduslik tekst imiteerib ühtaegu nii sündmusi, mis kuuluvad otseselt ajaloo või meie reaalse kogemuse valdkonda, kui moodust, kuidas me neist kõnelme või neid kirjeldame. 3. Konventsionaalsuse printsiip, mis eeldab retsipiendi poolt omandatud ja kirjandustekstis edastatud konventsioonide ühisust. 4. Retoorilise korrastatuse printsiip, mille puhul reaalsus kui korrastatud süsteem vastab teose retooriliste elementide süsteemsele korrastatusele.

Artikli autor vaatleb teksti ja reaalsuse sarnastumise vorme ja printsiipe kui 'mudelite' ehitamise mooduseid. Sellest tulenevalt avab ta mõiste 'mudel' erinevaid tähendusi läbi nende suhte 'originaalidesse', arvestades samas ka kunstiloomingu omadust esitada ja realiseerida üheaegselt mitut omavahel konflikteeruvat mudelit. Suhe reaalsusesse on antud juhul üles ehitatud klassikalise retoorika aristotelesliku variandi 
kohaselt ning seisneb lugejapoolses veendumuses ja usalduses. Rõhutatud on ka 'mudeli' kognitiivsed ja lugejat kujundavad omadused. Teksti autori ('modelleerija'/ jutustaja) ja lugeja / interpreteerija suhted rajanevad sümmeetria seadusel, kusjuures mõistmise jaoks on vajalik, et lugeja või auditoorium omandaksid neile vastava 'mudeli'. Autorit ja lugejat ühendavaks tähtsaimaks lüliks on see, et nad kasutavad ühte keelt nii olnu kui mitteolnu kirjeldamiseks.

Kirjanduse lugemine eeldab spetsiifilist pingutust, mõistmaks kujuteldavat maailma nii kollektiivse kui individuaalse kogemuse vahendusel, mitte ainult dialoogipartneri mõistmist vaid ka teatud määral tema seisukohtade omaksvõtmist. 